\title{
RISK FACTORS OF EXCESSIVE BODY MASS IN CHILDREN AND ADOLESCENTS IN LÓDŹ
}

\author{
Agnieszka Kolmaga ${ }^{1}$, Elżbieta Trafalska ${ }^{1}$, Franciszek Szatko ${ }^{2}$
}

\author{
${ }^{1}$ Zakład Żywienia i Epidemiologii, Katedra Higieny i Epidemiologii, Uniwersytet Medyczny w Łodzi \\ ${ }^{2}$ Zakład Higieny i Promocji Zdrowia, Uniwersytet Medyczny w Łodzi
}

\begin{abstract}
Background. Obesity and cardiovascular disease and metabolic disorders are an increasingly common problem worldwide, also in the developmental age population. Inhibiting this process requires identifying risk factors that can be modified. Objective. The aim of the study was to identify the conditions of the occurrence of overweight and obesity in the Lodz youth at school age.

Materials and methods. The survey was conducted in 2008-2012 among school students attending primary and secondary schools in the four districts of Lodz (city in Poland). The study involved 622 students aged 12-18: 309 girls (49.7\%) and 313 boys (50.3\%). The BMI index was calculated based on anthropometric measurements (mass, body height) and was interpreted on the basis of centile charts of Lodz children (overweight $\geq 85-95$ centile; obese $\geq 95$ centile). Youth health behaviors were analyzed based on a questionnaire of an original interview modeled on the HBSC (Health Behavior in School-aged Children) study. The obtained results were subjected to statistical analysis (single- and multi-factorial logistic regression analysis).

Results. An excess of body weight was found in $23.5 \%$ of the examined youth. In multivariate logistic regression analysis, the factors significantly affecting the occurrence of overweight or obesity were: non-eating dinner (daily or sometimes, $\mathrm{OR}=1.98)$; not eating fruit and vegetables every day $(\mathrm{OR}=1.57)$, multi-hour passive relaxation time (use of $\mathrm{TV}$, Internet, $\mathrm{OR}=3.08)$ and low physical activity $(\mathrm{OR}=1.76)$

Conclusions. Intensive promotion of a healthy lifestyle - increasing the awareness and knowledge of schoolchildren, encouraging proper eating habits and active leisure activities - can significantly affect the reduction of obesity risk factors. Health education is required at school for children, as well as for parents and teachers.
\end{abstract}

Key words: excessive body mass, risk factors, school youth, children, overweight

\section{STRESZCZENIE}

Wprowadzenie. Otyłość oraz choroby układu krążenia i zaburzenia metaboliczne są na całym świecie coraz częstszym problem, również w populacji wieku rozwojowego. Zahamowanie tego procesu wymaga określenia czynników ryzyka, które można modyfikować.

Cel badań. Celem pracy była identyfikacja uwarunkowań występowania nadwagi i otyłości u młodzieży łódzkiej w wieku szkolnym.

Material i metody. Badanie przeprowadzono w latach 2008-2012 wśród młodzieży szkolnej uczęszczającej do szkół podstawowych i ponadpodstawowych na terenie 4 dzielnic Łodzi. W badaniach uczestniczyło 622 uczniów w wieku 12-18 lat: 309 dziewcząt (49,7\%) i 313 chłopców (50,3\%). Na podstawie pomiarów antropometrycznych (masy, wysokości ciała) obliczono wskaźnik BMI, który interpretowano w oparciu o siatki centylowe dzieci łódzkich (nadwaga $\geq 85-95$ centyl; otyłość $\geq 95$ centyla). Zachowania zdrowotne młodzieży, analizowano w oparciu o kwestionariusz autorskiego wywiadu wzorowanego na badaniu HBSC (Health Behaviour In School-aged Children). Uzyskane wyniki badań poddano analizie statystycznej (jedno- i wieloczynnikowa analiza regresji logistycznej).

Wyniki. Stwierdzono nadmiar masy ciała u 23,5\% badanej młodzieży. W wieloczynnikowej analizie regresji logistycznej, czynnikami istotnie wpływającymi na występowanie nadwagi lub otyłości były: niespożywanie kolacji (codziennie lub czasami; $\mathrm{OR}=1,98)$; niespożywanie codziennie owoców i warzyw $(\mathrm{OR}=1,57)$, wielogodzinny czas wypoczynku biernego (korzystanie z telewizji, Internetu; $\mathrm{OR}=3,08)$ oraz mała aktywność fizyczna $(\mathrm{OR}=1,76)$.

Wnioski. Intensywne promowanie zdrowego stylu życia - zwiększanie świadomości i wiedzy młodzieży szkolnej, zachęcanie do prawidłowych nawyków żywieniowych oraz aktywnego spędzania wolnego czasu - może znacząco wpłynąć na redukcję czynników ryzyka otyłości. Konieczna jest edukacja zdrowotna prowadzona w szkole dla dzieci, a także dla rodziców i nauczycieli.

Słowa kluczowe: nadmierna masa ciała, czynniki ryzyka, młodzież szkolna, dzieci, nadwaga

Corresponding author: Agnieszka Kolmaga, Zakład Żywienia i Epidemiologii, Katedra Higieny i Epidemiologii, Uniwersytet Medyczny w Łodzi, tel. +48 4227252 88, e-mail: agnieszka.kolmaga@umed.lodz.pl

(C) Copyright by the National Institute of Public Health - National Institute of Hygiene 


\section{INTRODUCTION}

Currently, one of the biggest health problems of children and adolescents is excess body weight. Being awary of the seriousness of the physical and psychological consequences of obesity, many researchers are looking for conditions for its occurrence in children and adolescents $[8,36]$. Obesity is a chronic disease, conditioned by both environmental and psychosocial factors as well as genetic predisposition [15, 22, 34].

According to Oblacińska et al. [25] and other authors among environmental and behavioral obesity conditions, we can distinguish:

- nutritional: unbalanced diet, irregularity of eating and leaving out meals, eating snacks with high energy value (fast food, chips, sweets, sweet carbonated drinks) between meals, low fiber intake (fruit and vegetables, whole grains); nutritional factors determine $20-40 \%$ obesity in children $[27,50]$;

- inadequate energy expenditure related to low physical activity (unwillingness to exercise activities) and preference for activities related to the sedentary lifestyle (television / computer);

- family: occurrence of obesity in closest family members, poor socio-economic situation, family lifestyle, low education of parents - especially mothers [28, 52];

- social: the influence of the environment favoring obesity (civilizational influences) - greater possibilities of food purchase, easy access and advertising of high-calorie food products, larger portions sold at a proportionally lower price, reduced opportunities for recreational activity, increased use of motorized transport, eg to school, barriers to physical activity (eg insufficient number of sports facilities, bicycle paths), prolonging recreation time in a sitting position [42];

- psycho-emotional factors: satisfying emotional needs through eating- eating foods can compensate for the failures and difficulties experienced, distracting the child from the difficult situation and the unpleasantness in the family, at school or in a peer group [27]; lack of ability to cope with stress [22];

- other physiological and psychological factors that may contribute to obesity include: eating too fast, low sensitivity to a "feedback" mechanism indicating being saturated [51], and short time sleep [23].

The aim of the study was to identify the conditions of the occurrence of overweight and obesity in the Lodz youth at school age.

\section{MATERIALS AND METHODS}

The survey was conducted in 2008-2012 among school students attending primary and secondary schools in the four districts of Lodz (city in Poland).
The study involved 622 students aged 12-18: 309 girls (49.7\%) and 313 boys (50.3\%). Anthropometric measurements (mass, body height) were made and the BMI (Body Mass Index) was calculated. The results were interpreted on the basis of centile charts of Lodz children [30], using the following criteria: weight deficiency $\leq 10$ percentile; correct body mass ratio in relation to the 10-85 percentile increase; overweight $\geq 85-95$ percentile; obesity $\geq 95$ percentile). Eating habits, school and out-of-school activities, passive spending of time by young people, were analyzed based on a questionnaire of an original interview modeled on the HBSC (Health Behavior in Schoolaged Children) study. Statistical program Statistica 9.0 was used for statistical analysis of the obtained results. In order to determine the relationship between adverse health behaviors of adolescents and the occurrence of excessive body weight, variables from the questionnaire were compared (favorable and unfavorable health behaviors) and logistic regression analysis was performed to identify those features that significantly increased the occurrence of overweight and obesity in the studied youth.

\section{RESULTS}

Adolescents with normal nutritional status accounted for $70.3 \%$ of the study population, body mass deficiency occurred in $6.3 \%$ of students, while overweight and obesity was diagnosed in $23.5 \%$ of adolescents (Table 1).

Table 1. Nutrition status of adolescents according to BMI including centile grids (in \%)

\begin{tabular}{|l|c|c|}
\hline \multicolumn{1}{|c|}{ Nutritional status } & \multicolumn{2}{c|}{ Youth $(\mathrm{n}=622)$} \\
\hline Underweight $\leq 10 \mathrm{c}$ & $\mathrm{n}=39$ & 6.3 \\
\hline Standard $10 \mathrm{c}-85 \mathrm{c}$ & $\mathrm{n}=437$ & 70.3 \\
\hline Overweight $85 \mathrm{c}-95 \mathrm{c}$ & $\mathrm{n}=89$ & 14.3 \\
\hline Obesity $\geq 95 \mathrm{c}$ & $\mathrm{n}=57$ & 9.2 \\
\hline
\end{tabular}

In order to estimate the risk of overweight-obesity in the study, a univariate and multivariate logistic regression analysis was applied. In the univariate logistic regression analysis (Table 2), the factors significantly influencing the occurrence of overweightobesity turned out to be 6 out of 27 features selected for this analysis. In comparison with people who eat supper regularly, those who do not eat it, are almost twice as often more obese or overweight $(\mathrm{OR}=1.98$, $\mathrm{p}<0.05)$. Not consuming fruit and vegetables every day increases this risk by 1.5 times $(\mathrm{OR}=1.57, \mathrm{p}<0.05)$. Passive rest of the respondents, measured by the number of hours of using television, Internet or computer games, increases the risk of overweight - obesity. 
Table 2. Estimation of the influence of traits (risk) of overweight - obesity among adolescents based on a one-factor logistic regression analysis

\begin{tabular}{|c|c|c|c|c|}
\hline \multicolumn{2}{|l|}{ Variable } & \multirow{2}{*}{$\begin{array}{c}\begin{array}{c}\text { Odds } \\
\text { ratio }\end{array} \\
1.13 \\
\end{array}$} & \multirow{2}{*}{$\begin{array}{c}95 \% \mathrm{CI} \\
0.78-1.63\end{array}$} & \multirow{2}{*}{$\begin{array}{c}\mathrm{P} \\
\mathrm{p}>0.05\end{array}$} \\
\hline & Boys & & & \\
\hline Gender & Girls & 1.00 & Reference group & \\
\hline \multirow{3}{*}{ Age } & 12 years & 1.54 & $0.96-2.47$ & $\mathrm{p}>0.05$ \\
\hline & 16 years & 1.03 & $0.67-1.57$ & $\mathrm{p}>0.05$ \\
\hline & 18 years & 1.00 & Reference group & \\
\hline \multirow{2}{*}{ First breakfast } & No consumption & 1.001 & - & $\mathrm{p}>0.05$ \\
\hline & Consumption & 1.00 & Reference group & \\
\hline \multirow{2}{*}{ Second breakfast } & No consumption & 0.76 & $0.41-1.42$ & $\mathrm{p}>0.05$ \\
\hline & Consumption & 1.00 & Reference group & \\
\hline \multirow{2}{*}{ Diner } & No consumption & 0.59 & $0.23-1.17$ & $\mathrm{p}>0.05$ \\
\hline & Consumption & 1.00 & Reference group & \\
\hline \multirow{2}{*}{ Supper } & No consumption & 1.98 & $1.02-3.86$ & $\mathrm{p}<\mathbf{0 . 0 5}$ \\
\hline & Consumption & 1.00 & Reference group & \\
\hline \multirow{2}{*}{ Everyday consumption of milk } & No & 0.72 & $0.49-1.05$ & $\mathrm{p}>0.05$ \\
\hline & Yes & 1.00 & Reference group & \\
\hline \multirow{2}{*}{ Daily consumption of milk products } & No & 1.05 & $0.72-1.53$ & $\mathrm{p}>0.05$ \\
\hline & Yes & 1.00 & Reference group & \\
\hline \multirow{2}{*}{ Eating meat every day or several times a week } & No & 0.36 & $0.11-1.22$ & $\mathrm{p}>0.05$ \\
\hline & Yes & 1.00 & Reference group & \\
\hline \multirow{2}{*}{ Eating fish every day or several times a week } & No & 0.71 & $0.47-1.08$ & $\mathrm{p}>0.05$ \\
\hline & Yes & 1.00 & Reference group & \\
\hline \multirow{2}{*}{ Daily consumption of cereal products } & No & 1.19 & $0.79-1.77$ & $\mathrm{p}>0.05$ \\
\hline & Yes & 1.00 & Reference group & \\
\hline \multirow{2}{*}{ Daily consumption of whole meal bread } & No & 0.65 & $0.43-1.00$ & $\mathrm{p}>0.05$ \\
\hline & Yes & 1.00 & Reference group & \\
\hline \multirow{2}{*}{ Non-consumption of legumes } & No & 0.92 & $0.64-1.34$ & $\mathrm{p}>0.05$ \\
\hline & Yes & 1.00 & Reference group & \\
\hline \multirow{2}{*}{ Daily consumption of fruits and vegetables } & No & 1.57 & $1.07-2.29$ & $\mathrm{p}<\mathbf{0 . 0 5}$ \\
\hline & Yes & 1.00 & Reference group & \\
\hline \multirow{2}{*}{ Daily consumption of carbonated drinks } & Yes & 1.20 & $0.78-1.85$ & $\mathrm{p}>0.05$ \\
\hline & No & 1,00 & Reference group & \\
\hline 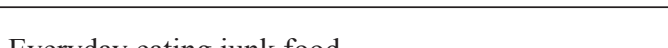 & Yes & 0.75 & $0.51-1.08$ & $\mathrm{p}>0.05$ \\
\hline Everyday eatıng junk food & No & 1.00 & Reference group & \\
\hline 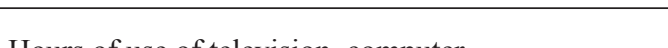 & Change by 1 hour & 1.10 & $1.01-1.20$ & $\mathrm{p}<0.05$ \\
\hline Hours of use of television, computer & Change by entire range & 3.08 & $1.06-8.91$ & \\
\hline 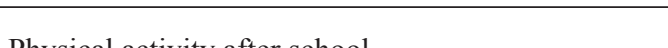 & Little & 1.76 & $1.11-2.79$ & $\mathrm{p}<\mathbf{0 . 0 5}$ \\
\hline Physical activity after school & High or medium & 1.00 & Reference group & \\
\hline Fyercice in nhycicol education clacses & No & 0.90 & $0.50-1.63$ & $\mathrm{p}>0.05$ \\
\hline Exercise in physical education classes & Yes & 1.00 & Reference group & \\
\hline & Basic/vocational & 1.40 & $0.61-3.25$ & $\mathrm{p}>0.05$ \\
\hline Mother's education & Secondary education & 1.29 & $0.69-2.43$ & $\mathrm{p}>0.05$ \\
\hline & Higher education & 1.00 & Reference group & \\
\hline Fncouregement of phycical activity by parents & No & 1.32 & $0.86-2.04$ & $\mathrm{p}>0.05$ \\
\hline Encouragement of physical activity by parents & Yes & 1.00 & Reference group & \\
\hline Wetching TV ovor 2 b doilus & Yes & 0.95 & $0.62-1.37$ & $\mathrm{p}>0.05$ \\
\hline Watching TV over $2 \mathrm{~h}$ daily & No & 1.00 & Reference group & \\
\hline Ucing the Intornet mone then 4 houre doilve & Yes & 0.83 & $0.53-1.30$ & $\mathrm{p}>0.05$ \\
\hline Using the Internet more than 4 hours daily & No & 1.00 & Reference group & \\
\hline Time for computer oame lonor then $2 \mathrm{~b}$ doil & Yes & 1.04 & $0.67-1.63$ & $\mathrm{p}>0.05$ \\
\hline Time for computer games longer than $2 \mathrm{~h}$ daily & No & 1.00 & Reference group & \\
\hline Niobt anct 56 houm & Yes & 1.25 & $0.80-1.93$ & $\mathrm{p}>0.05$ \\
\hline Night rest 5-6 hours & No & 1.00 & Reference group & \\
\hline Coino to loon not loton thon 11 nm & Yes & 0.49 & $0.33-0.71$ & p $<0.001$ \\
\hline Going to sleep not later than at $11 \mathrm{pm}$ & No & 1.00 & Reference group & \\
\hline More frequent snacking of fruit and vegetables than & Yes & 0.61 & $0.99-2.71$ & $\mathrm{p}<\mathbf{0 . 0 5}$ \\
\hline sweets and crisps & No & 1.00 & Reference group & \\
\hline
\end{tabular}


If the seating time increases by 1 hour, the risk increases by $10 \%(\mathrm{OR}=1.10, \mathrm{p}<0.05)$, and if it increases by the whole range of variability, then the risk increases 3 times $(\mathrm{OR}=3.08, \mathrm{p}<0.05)$. In students who declared that in addition to physical education classes, they rarely take (or not at all) physical activity in their spare time (low physical activity) - the risk of overweightobesity is almost twice as high as in adolescents who exercise at least 2-3 times more often in a week, min. 60 min. (average and high physical activity) $(\mathrm{OR}=1.76, \mathrm{p}$
$<0.05)$. Going to bed at no later than $11 \mathrm{pm}$ reduces the risk of overweight- obesity twice $(\mathrm{OR}=0.49, \mathrm{p}<0.001)$. If snacking includes more frequently beneficial products (fruit and vegetables) than not beneficial to health (sweets, crisps) - it is a positive difference, the risk of overweight and obesity becomes almost twice as low $(\mathrm{OR}=0,61, \mathrm{p}<0.05)$. In the overweight and obesity group sweets and crisps were more often consumed than fruit and vegetables.

Table 3. Estimation of the influence of traits (risk) of overweight - obesity among adolescents based on multivariate logistic regression analysis

\begin{tabular}{|c|c|c|c|c|}
\hline \multicolumn{2}{|c|}{ Variable } & Odds ratio & $95 \% \mathrm{CI}$ & $\mathrm{P}$ \\
\hline \multirow{2}{*}{ Supper } & No consumption & 2.75 & $1.03-7.31$ & $\mathrm{p}<0.05$ \\
\hline & Consumption & 1.00 & Reference group & \\
\hline \multirow{2}{*}{$\begin{array}{l}\text { Everyday consumption of fruit and } \\
\text { vegetables }\end{array}$} & No & 1.86 & $1.01-3.44$ & $\mathbf{p}<0.05$ \\
\hline & Yes & 1.00 & Reference group & \\
\hline \multirow{2}{*}{$\begin{array}{l}\text { Time watching } \mathrm{TV} \text {, using computer } \\
\text { (passive rest) }\end{array}$} & Change by 1 hour & 1.21 & $1.08-1.42$ & $\mathbf{p}<\mathbf{0 . 0 1}$ \\
\hline & Change by the entire range & 3.41 & $2.57-62.02$ & \\
\hline \multirow{2}{*}{ Physical activity } & Little & 1.82 & $1.03-3.21$ & $\mathrm{p}<0.05$ \\
\hline & High or medium & 1.00 & Reference group & \\
\hline \multirow{2}{*}{ Going to sleep no later than at $11 \mathrm{pm}$} & Yes & 0.58 & $0.32-1.03$ & $\mathbf{p}<\mathbf{0 . 0 5}$ \\
\hline & No & 1.00 & Reference group & \\
\hline \multirow{2}{*}{$\begin{array}{l}\text { More frequent snacking of fruit and } \\
\text { vegetables than sweets and crisps }\end{array}$} & Yes & 0.55 & $0.30-1.03$ & $p=0.05$ \\
\hline & No & 1.00 & & \\
\hline
\end{tabular}

In multivariate logistic regression analysis, (Table 3) in which important features in a univariate analysis were taken into account, the following were important: leaving out supper (those who do not eat, are obese or overweight almost three times more often $(\mathrm{OR}=2.75 ;<0.05)$, not consuming fruit and vegetables every day increases this risk almost twice $(\mathrm{OR}=1.86, \mathrm{p}<0.05)$, similarly low physical activity $(\mathrm{OR}=1.82, \mathrm{p}<0.05)$; use of television and computer $(\mathrm{p}<0.01)$ - if the seating time increases by 1 hour, the risk increases by $20 \%(\mathrm{OR}=1.21)$, and if it increases by the entire range of volatility, then the risk increases over 3 times $(\mathrm{OR}=3.41)$, going to bed not later than at $11 \mathrm{pm}$ o'clock $(\mathrm{OR}=0.58, \mathrm{p}$ $<0.05$ ) and snacking - a positive difference - more often fruit and vegetables as snacks than sweets and crisps - the risk of overweight and obesity becomes almost twice as low $(\mathrm{OR}=0.55, \mathrm{p}=0.05)$.

\section{DISCUSSION}

Too small number of meals and their irregular consumption increases the risk of overweight and obesity. Too long breaks between meals cause a feeling of hunger and the desire to eat sweet or fatty (highcalorie) products to quickly compensate for energy shortages. The body demands regular supply of the right amount of energy and nutrients. If meals are consumed irregularly, the body begins to accumulate energy for periods of hunger in the form of adipose tissue [49]. Therefore, children who eat one or two large meals during the day are more likely to gain weight than those who have the same amount of food receive in 4-6 meals [32]. It is worth noting that, in the opinion of the young people, regular daily meals are of no importance for health and maintaining a healthy weight [47]. There is a widespread belief that reducing the number of meals consumed during the day is a good method of reducing the caloric intake of food [10]. Many studies indicate that children who are overweight and obese eat fewer meals during the day than their peers with normal body mass and they eat irregularly. They often erroneously treat giving up a meal (mostly breakfast) as a form of slimming diet [49].

In the own study, an important factor increasing the occurrence of excessive body weight was not eating supper. Rampersand et al. [37] observed a relationship between non-eating of breakfast and the occurrence of excessive body weight in the subjects. Nicklas et al. [24] noted that children who regularly eat breakfast, eat more cereal products, fruit and dairy products, which helps maintain a healthy weight. In addition, eating breakfast is associated with a lower consumption of high-fat and high-calorie snacks throughout the day $[20,41]$. In the Olszanecka-Glinianowicz et al. study [29] in girls at prepubertal age, not eating breakfast 
increased the risk of developing obesity, whereas in boys it was important to eat outside the home. 11-13 year-old children from Warsaw who were diagnosed with obesity, most often among the respondents $(16.1 \%)$ declared consumption of less than 3 meals a day, than children with normal body weight (1.4\%) [48]. Similar observations have been made in other studies. Children/adolescents with overweight and obesity consumed significantly less meals than children without excess body weight $[11,41]$. On the other in the studies of Gajda and Jeżewska-Zychowicz [6], incorrect eating habits of adolescents regarding eating sapper were observed (especially among girls). According to the authors, this was most probably the result of an wrong way of maintaining a healthy body mass that could lead to eating disorders. However, in studies by Stawińska et al. [39], a significant relationship was found between not eating a second breakfast and a more frequent use of a slimming diet in a group of 12-16 year old girls. The tendency to abandon supper, as well as leaving out breakfast, is often associated with a desire to reduce body mass [17]. Children/adolescents with excessive body mass may therefore attempt to control the amount of calories consumed by limiting the number of meals, which may have the opposite consequences to the intentions [1].

Another risk factor for overweight and obesity in the 12-18 year old population in the author's own work was not eating vegetables and fruit every day. Similar results were obtained by Wolnicka and JaczewskaSchuetz [48]. The factors preventing excessive body weight may the consumption of vegetables and fruit at least 1-2 times a day. A stronger protective factor can be eating fruit and vegetables even more often 3-5 times a day. Oblacinska study [25] also proved that middle- school students with overweight and obesity consumed products indispensable for health (fruit, vegetables, brown bread, milk and its products) at an unsatisfactory level. Similarly, in the study Ledikwe et al. [18] it was observed that obese people did not consume enough fruit and vegetables. The high proportion of vegetables and fruits, legumes, nuts and whole grains (high content of dietary fibers) in the diet have a preventive effect in relation to the development of excessive body weight $[19,44]$.

Just observing a low-energy diet and avoiding certain foods or leaving basic meals in itself does not guarantee due weight. The nutritional education of the child and his family in the aspect of proper eating habits is important, including the regular consumption of meals (preferably together with the family) and daily fruit and vegetable intake and appropriate physical activity $[11,25,43,52]$.

Systematic physical activity plays a key role in the prevention and treatment of overweight and obesity [5, 9]. The results of the author's own work have shown that a significant factor increasing the risk of excessive body weight was low physical activity of the subjects. In the study of Silesian children - it was also found that in 7-9 year-old girls low physical activity increased the risk of developing obesity [29]. In other Polish studies [26], junior high school students with excess body mass compared to their peers with the correct weight, did less often take part in physical education lessons and participated in extracurricular physical activities or sport. Over $1 / 3$ of obese adolescents did not participate regularly or did not take part in physical education classes (especially girls). A negative image of one's body, difficulties in its acceptance, fear of being ridiculed are an obstacle to physical activity, especially in the case of obese girls [12]. According to studies by $S o$ et al. [40], the smallest percentage of girls and boys with obesity participated in physical education lessons, compared to young people with deficiency and normal body mass. Fenczyn et al. [4] stated in their research that obese girls and boys more often than their peers did not take part in physical education lessons at school and did not exercise in their free time. After classes at school, adolescents with obesity more often chose reading books, talking with friends, watching TV. Similarly, other researchers showed that obese people were less active compared to peers with normal body weight $[31,33,45]$. In the population of 17-year-olds [35], physically active people had lower body mass, BMI and fat content in the body, in comparison with those who were not physically active. Similarly, in Kasperczyk et al. [14].

In some studies, there were no statistically significant differences between body weight or BMI and physical activity presented [16, 21].

Time spent in front of the TV or computer screen above 4.5 hours was a significant factor increasing the risk of overweight and obesity in the group of the studied youth. The obtained results in the own study are consistent with the observations of other authors $[2,38]$. Among the children who spent 5 hours a day in front of the TV there were over 5 times more people with excess body weight than among peers who watched TV programs below 2 hours a day [7]. Based on NHANES - The National Health and Nutrition Examination Survey, the highest incidence of overweight and obesity in children who watched TV $\geq 4$ hours and the lowest in those who watched $\leq 1$ hours a day was demonstrated [3].

In the literature on the subject, you can also find works in which there is no significant impact of time spent in front of the TV/computer on the body mass of the tested youth [13, 35, 41, 46]. According to Jodkowska et al. [13] behaviors related to passive lifestyle are not competitive in relation to physical activity in Polish teenagers, while their relationship with abnormal nutritional behaviors (eating sweets, crisps, drinking carbonated beverages) may lead to the development of obesity. 


\section{CONCLUSIONS}

1. Intensive promotion of a healthy lifestyle increasing the awareness and knowledge of schoolchildren, encouraging proper eating habits and active leisure activities - can significantly affect the reduction of obesity risk factors.

2. Health education is required at school for children, as well as for parents and teachers. Activities in nutrition education for children should be carried out by nutritionists and for parents and guardians, activities / workshops should be organized before obligatory monthly consultations.

\section{Conflict of interest}

The authors declare no conflict of interest.

\section{REFERENCES}

1. Albertson AM., Thompson D., Franko D.L., Kleinman R.E., Barton B. A., Crockett S.J: Consumption of breakfast cereal is associated with positive health outcomes: evidence from the National Heart, Lung, and Blood Institute Growth and Health Study. Nutr Res 2008; 28 (11): 744-752.

2. Arluk S.L., Branch J.D., Swain D.P. Dowling E.A.: Childhood obesity's relationship to time spent sedentary behaviour. Mil. Med., 2003; 168: 583-586.

3. Crespo C.J., Smit E., Troiano R.P., Bartlett S.J., Macera C.A., Andersen R.E.: Television Watching, Energy Intake, and Obesity in US Children: Results From the Third National Health and Nutrition Examination Survey, 19881994. Arch. Pediatr. Adolesc. Med. 2001; 155: 360-365

4. Fenczyn J., Szmigiel Cz.: Attitude towards physical activity among boys and girls with simple obesity. Stud. Phys. Cultur. Tourism. 2006; 13 (2): 33-41.

5. Frelut M.L.: Aktywność fizyczna a otyłość. [w:] Tounian $P$. [red.:] Otyłość u dzieci. Wydawnictwo Lekarskie PZWL, Warszawa 2008: 124-135.

6. Gajda R., Jeżewska-Zychowicz M.: Zachowania żywieniowe młodzieży mieszkającej w województwie świętokrzyskim-wybrane aspekty. Probl Hig Epidemiol 2010; 91 (4): 611-617

7. Gutkowska-Wyka A.: Podejścia terapeutyczne do redukcji nadwagi u dzieci i młodzieży. Endokrynol Ped 7/2008; 4, 25: 55-64.

8. Izdebski P., Rucińska - Niesyn A.: Psychologiczne uwarunkowania otyłości u dzieci - rola rodziny. Uniwersytet Kazimierza Wielkiego w Bydgoszczy, 2009: $149-159$.

9. Jarosz M., Wolnicka K., Kłosowska J.: Czynniki środowiskowe związane $\mathrm{z}$ występowaniem nadwagi i otyłości wśród dzieci i młodzieży. Post Nauk Med 2011; 9: 770-777.

10. Jeżewska-Żychowicz M.: Stereotypy w myśleniu o żywności w kontekście jej wpływu na masę ciała. Rocz Państw Zakł Hig 2007; 58 (2): 437-444.

11. Jodkowska M., Oblacińska A., Tabak I., Radiukiewicz $K$.: Differences in dietary patterns between overweight and normal weight adolescents. Med Wieku Rozw 2011; 15 (3): 266-273.

12. Jodkowska M., Oblacińska A., Tabak I., Radiukiewicz $K$.: Rola nauczycieli wychowania fizycznego w opiece czynnej nad uczniami z nadwagą i otyłością. Med Wieku Rozw 2010; 14 (2): 197-206.

13. Jodkowska M., Tabak I., Oblacińska A., Stalmach M.: Siedzący tryb życia polskich 13-latków i jego powiązania z wybranymi zachowaniami zdrowotnymi, praktykami rodzicielskimi oraz masą ciała. Med Wieku Rozw 2013; 17 (2): 165-173.

14. Kasperczyk J., Jośko J., Bliska J.: Sposób odżywiania się oraz wybrane czynniki zdrowego stylu życia wśród młodzieży licealnej. Prob Hig Epidemiol 2007; 88 (2): 157-161.

15. Kołodziejczyk H., Rudzka- Kocjan A., Rysiewski H., Szalecki M., Ksiażyk J. B.: Ocena tkanki tłuszczowej i beztluszczowej dziewcząt i chłopców z otyłością przed i po leczeniu dietetyczno-rehabilitacyjnym. Endokrynol Ped 2011; 103 (36): 23-28

16. Kubasiak-Stonina A., Grzegorczyk J., Mazur A.: Ocena sprawności i aktywności fizycznej dzieci szkolnych $\mathrm{z}$ nadmierną i prawidłową masą ciała. Endokrynol Otyłość 2012; 8 (1): 16-23

17. Lattimore PJ., Halford JCG.: Adolescence and the dietdieting disparity: healthy food choice or risky health behaviors? Br. J. Health Psychol. 2003; 8 (4): 451 - 460

18. Ledikwe J.H., Smiciklas-Wright H., Mitchell D.C., Jensen G.L., Friedmann J.M., Still C.D.: Nutritional risk assessment and obesity in rural older adults: a sex difference. Am. J. Clin. Nutr. 2003; 77: 551-558

19. Lin BH, Morrison RM.: Higher fruit consumption linked with lower body mass index. Food Rev. 2002; 25: 28-32

20. Małecka-Tendera E., Zachurzok-Buczyńska A.: Otyłość i zespół metaboliczny u dzieci i młodzieży. [w:] Podolec P. [red.:] Podręcznik PFP Medycyna Praktyczna, Kraków 2010

21. Marcysiak M., Zagroba M., Ostrowska B. Wiśniewska E., Marcysiak M., Skotnicka-Klonowicz, G.: Aktywność fizyczna, a zachowania żywieniowe dzieci i młodzieży powiatu ciechanowskiego. Probl Pielęg 2010; 18 (2): $176-183$

22. Mazur A., Klimek K., Małecka - Tendera E.: Czynniki ryzyka występowania otyłości u dzieci szkolnych w województwie podkarpackim. Endokrynol Otyłość 2011; 7 (3): 157-166

23. Mazur J., Tabak I., Gajewski J., Dzielska A.: Nadwaga i otyłość wśród uczniów gimnazjum w zależności od wybranych czynników behawioralnych. Zmiany w latach 2006 - 2010. Prz Epidemiol; 2012; 66: 503 $-508$

24. Niclas T.A., Baranowsky T., Cullen K.W.: Eating patterns, dietary quality and obesity. J. Am. Coll. Nutr., 2001; 20, 6: 599-608

25. Oblacińska A.: Wspieranie dziecka $\mathrm{z}$ nadwagą i otyłością w społeczności szkolnej. Ośrodek Rozwoju Edukacji, Warszawa 2013

26. Oblacińska A., Jodkowska M. [red.:] Otyłość u polskich nastolatków. Epidemiologia, styl życia, samopoczucie. IMiD, Warszawa 2007 
27. Oblacińska A., Weker H. [red.:] Profilaktyka otyłości u dzieci i młodzieży. Od urodzenia do dorosłości. Wydawnictwo Help \& Med., Kraków 2008

28. Obuchowicz A.: Otyłość dzieci i młodzieży - przyczyny, sposoby oceny i metody zapobiegania. PFP Chorób Układu Krążenia, 2007; 3, 8, www.pfp.edu.pl

29. Olszanecka-Glinianowicz M., Małecka-Tendera E., Klimek K., Matusik P., Żak-Gołab A.: Czynniki ryzyka otyłości prostej u dzieci śląskich w wieku 7-9 lat. Endokrynol Ped 5/2006; 2 (15): 31-38

30. Ostrowska-Nawarycz L., Nawarycz T.: Ciśnienie tętnicze oraz parametry i wskaźniki stanu odżywienia u dzieci i młodzieży łódzkiej w wieku 3-19 lat-Normy, postępowanie diagnostyczne, prewencja, Wydział Zdrowia i Wydział Edukacji Urzędu Miasta Łodzi, Uniwersytet Medyczny w Łodzi. Łódź 2008

31. Patrick K., Norman GJ. Calfas KJ., Sallis JF.: Diet, Physical Activity, and Sedentary Behaviors as Risk Factors for Overweight. Arch. Pediatr. Adolesc. Med. 2004; 158, 4: 385-390

32. Platta A., Martul A.: Ocena wiedzy rodziców w zakresie wpływu nieprawidłowych zachowań żywieniowych na rozwój otyłości prostej u dzieci. Bromat Chem Toksykol 2012; 45, 3: 1087- 1091

33. Popławska H., Dmitruk A., Hołub W.: Aktywność fizyczna dzieci i młodzieży wiejskiej zagrożonych wystąpieniem w przyszłości zaburzeń sercowonaczyniowych. Med Og Nauk Zdr 2013; 19, 2: 177-182

34. Przybylska D., Kurowska M., Przybylski P.: Otyłość i nadwaga w populacji rozwojowej. Hygeia Public Health 2012; 47, 1: 28-35

35. Przybytowicz K., Cichon R., Jaworska A.: Ocena wpływu wybranych elementów stylu życia młodzieży szkolnej na masę ciała i jej skład. Now Lek 2006; 75, 5, 460-465

36. Pysz M., Leszczyńska T., Cieślik E., Kopeć A., Wielgos B., Piatkowska E.: Relationship between the intake of energy and basic nutrients and the BMI values in group of children aged 10-12. Rocz Panstw Zakl Hig 2014; 65(4): 345-352

37. Rampersand G.C., Pereira M.A., Girard B.L. Gail C. Adams J., Metzl J.D.: Breakfast habits, nutritional status, body weight and academic performance in children and adolescents. J. Am. Diet. Assoc., 2005; 105: 743-760

38. Salbe A.D., Weyer C., Harper I., Lindsay R.S., Ravussin E., Tatarann P.A.: Assessing risk factors for obesity between childhood and adolescence: II. Energy metabolism and physical activity. Pediatrics, 2002; 110: 307-314

39. Stawińska T., Kochan K., Krynicka I. Blaha P.: Zachowania zdrowotne dzieci i młodzieży w wieku 7 - 16 lat. Rocz Państw Zakł Hig 2010; 61(2): 165- 169

40. SoW-Y., Sung D-J., Swearingin B., Beak S-I., Rhi $S-Y$., Webb D., Fuller T.M.: Prevalence of obesity in Korean adolescents and its relationship with the weekly frequency of the physical education classes. J. Sports Sci. Med. 2011; 10: 679-684

41. Stankiewicz M., Pieszko M., Śliwińska A., Małgorzewicz S., Wierucki L., Zdrojewski T., Wyrzykowski B., LysiakSzydłowska W.: Występowanie nadwagi i otyłości oraz wiedza i zachowania zdrowotne dzieci i młodzieży małych miast i wsi - wyniki badania Polskiego Projektu 400 Miast. Endokrynol Otyłość 2010; 6, 2: 59-66

42. Szostak-Wegierek D.: Zespół metaboliczny u dzieci i młodzieży jako wyzwanie do zdrowia publicznego. Probl Hig Epidemiolog 2008; 89 (1): 21-29

43. Tabak I., Jodkowska M., Oblacińska A., Mikiel-Kostyra $K$ : Czy spożywanie wspólnych posiłków z rodziną może chronić nastolatki przed otyłością. Med Wieku Rozw 2012; 16, 4: 313-321

44. Tohill BC, Seymour J, Serdula M., Kettel-Khan L., Rolls B.J.: What epidemiological studies tell us about the relationship between fruit and vegetable consumption and body weight. Nutrition Reviews 2004; 62: 365-374

45. Trost SG., Kerr LM., Ward DS., Pate RR.: Physical activity and determinants of physical activity in obese and non-obese children. Int. J. Obes. Relat. Metab. Disord. 2001; 25: 822-829

46. Velde S.J., De Bourdeaudhuij I., Thorsdottir I.: Patterns in sedentary and exercise behaviors and associations with overweight in 9-14-year-old boys and girls a cross-sectional study. BMC Public Health 2007; 7, 16 doi:10.1186/1471-2458-7-16.

47. Wojtyła A., Biliński P., Bojar I., Wojtyła C.: Zaburzenia odżywiania u polskich gimnazjalistów. Probl Hig Epidemiolog, 2011; 92, 2: 343-350.

48. Wolnicka K., Jaczewska-Schuetz J.: Weight status related to eating behaviors of school aged children in Warsaw. Post Nauk Med 2011; 9: 724-731.

49. Woynarowska B., Oblacińska A.: Wspólne drugie śniadanie w szkole. Poradnik dla dyrektorów i pracowników szkół oraz rodziców uczniów. Ośrodek Rozwoju Edukacji. Warszawa 2012

50. Woźniak A., Artych M., Wawrzyniak A.: Nutritional behaviours and body self-perception in polish pupils attending middle-school. Rocz Panstw Zakl Hig 2014; 65(4): 331-336.

51. Young I.: Jak wspierać rozwój i zdrowie młodzieży. Pakiet edukacyjny zgodny z koncepcją i metodami pracy szkoły promującej zdrowie. Ośrodek Rozwoju Edukacji. Warszawa 2011

52. Zielińska M., Hamułka J., Gajda K.: Family influences on breakfast frequency and quality among primary school pupils in Warsaw and its surrounding areas. Rocz Panstw Zakl Hig 2015; 66 (2): 143-149.

Received: 05.08.2019

Accepted: 22.10 .2019 